\title{
PENGARUH KARAKTERISTIK INDIVIDU, GAYA KEPEMIMPINAN DAN BUDAYA ORGANISASI TERHADAP KOMITMEN ORGANISASI PADA SEKRETARIAT DPRD KABUPATEN BOGOR
}

\author{
Maulana Yusuf Rukmana ${ }^{1)}$ Sri Harini ${ }^{2)}$ \\ Program Studi Manajemen, Fakultas Ekonomi, Universitas Djuanda Bogor \\ Email:maulana.yusuf.rukmana@unida.ac.id, sri.harini@unida.ac.id \\ Correspondence author : sri.harini@ unida.ac.id
}

\begin{abstract}
The aims of this research is to identify the individual's characteristics, the leadership style and the culture of organization effect on organization commitment at Secretariat DPRD regency Bogor. There are 69 respondents as the sample that were taken. The methods that used in this research are survey method, the form of description and quantitative. Observation, interview and questionnaire are used to collect the data of this research. The test of this research that used are the validity test, reliability test and assumption classic test with likert scale for the double linear regressio and the hypotheses test. The result of this research is all the indicators had valid and reliable as well as fulfill rules and regulations on the assumption classic is simultaneously the individual's characteristic $\left(X_{1}\right)$, the leadership style $\left(X_{2}\right)$, and the culture of organization $\left(X_{3}\right)$ influential in positive and significant toward organization commitment $(Y)$. In the partial the individual's characteristic $\left(X_{1}\right)$, the leadership style $\left(X_{2}\right)$ and the culture of organization $\left(X_{3}\right)$ influential in positive and significant toward organization commitment $(Y)$, while leadership style $\left(X_{3}\right)$ has not influential in positive and significant toward organization commitment $(Y)$.

Keywords: : the individual's Characteristic, the leadership style, the culture of organization, organization commitment
\end{abstract}

\begin{abstract}
ABSTRAK
Penelitian ini bertujuan untuk mengetahui pengaruh karakteristik individu, gaya kepemimpinan dan budaya organisasi terhadap komitmen organisasi pada Sekretariat DPRD Kabupaten Bogor. Pengambilan sampel berjumlah 69 orang responden. Metode yang digunakan dalam penelitian ini adalah metode survey, bentuk penelitian ini adalah deskriptif kuantitatif. Pengumpulan data dalam penelitian melalui observasi, wawancara dan penyebaran kuesioner kepada responden. Uji yang digunakan dalam penelitian ini menggunakan uji vailiditas, uji reliabilitas, uji asumsi klasik serta skala likert untuk regresi linear berganda dan uji hipotesis. Hasil penelitian ini menunjukkan semua indikator valid dan reliabel serta memenuhi persyaratan pada asumsi klasik secara simultan Karakteristik Individu ( $\left.\mathrm{X}_{1}\right)$, Gaya Kepemimpinan $\left(\mathrm{X}_{2}\right)$ dan Budaya Organisasi $\left(\mathrm{X}_{3}\right)$ berpengaruh secara positif dan signifikan terhadap Komitmen Organisasi (Y). Secara parsial Karakteristik Individu $\left(\mathrm{X}_{1}\right)$ dan Budaya Organisasi $\left(\mathrm{X}_{2}\right)$ berpengaruh secara positif dan siginifikan terhadap Komitmen Organisasi (Y), sedangkan Gaya Kepemimpinan $\left(\mathrm{X}_{3}\right)$ tidak berpengaruh secara positif dan signifikan terhadap Komitmen Organisasi (Y). Kata Kunci: Karakteristik Individu, Gaya Kepemimpinan, Budaya Organisasi, Komitmen Organisasi
\end{abstract}

\section{PENDAHULUAN}

Sebagai suatu unsur lembaga penyelenggara pemerintahan di Kabupaten Bogor, Dewan Perwakilan Rakyat Daerah (DPRD) Kabuaten Bogor terus berupaya menciptakan kondisi penyelenggaraan pemerintahaan yang baik. Upaya tersebut sesuai dengan peran dan fungsi DPRD yaitu melalui tugas pokok dan pelaksanaan fungsi legislasi dan pembuat kebijakan, anggaran dan pengawasan. Kegiatankegiatan kemudian diformulasikan ke dalam 
pelaksanaan tugas DPRD antara lain penetapan peraturan daerah yang bersifat partisipatif, APBD yang keberpihakan kepada rakyat, serta pelaksanaan pengawasan melalui komisi-komisi serta kegiatan Reses DPRD untuk menampung aspirasi masyarakata di masing-masing daerah pemilihan.

Pelaksanaan tugas pokok dan fungsi (Tupoksi) pemerintah dilaksanakan oleh Pemerintah Daerah (PEMDA) yaitu Pemerintahan Daerah dengan Dewan Perwakilan Rakyat Daerah (DPRD) yang memiliki hubungan kemitraan dan bekerjasama dalam membangun daerahnya, antara eksekutif dan legislatif tidak saling membawahi satu sama lain. Pemerintah Daerah dan DPRD bersamasama membentuk kebijakan untuk melakukan dan melaksanakan otonomi daerah sesuai dengan tugas pokok dan fungsi masing-masing sebagai suatu lembaga legislatif yaitu perwakilan rakyat ditingkat daerah, kedudukan DPRD diatur oleh Peraturan Pemerintah No 24 meningkatkan kapasitas kemampuan daerah adalah kemampuan manusianya dan pemerintahan daerah. Namun kenyataannya, berbagai permasalahan umum sering terjadi pemerintah daerah sendiri belum responsive dan proaktif dalam menanggapi berbagai perkembangan tersebut, sehingga dalam melayani masyarakat terkesan lamban dan masih memerlukan pembenahan disana-sini serta serta masih belum profesionalitas kinerja birokrasi.

Daftar DP3 pegawai Dewan Perwakilan Rakyat Daerah Kabupaten Bogor dapat dilihat dalam tabel berikut :

Tabel 1. Data Kinerja Pegawai

\begin{tabular}{ccc}
\hline Tahun & Kinerja Pegawai & Perubahan \\
\hline 2010 & 79,85 & - \\
2011 & 79,95 & 0,12 \\
2012 & 79,51 & $-0,55$ \\
2013 & 79,77 & 0,33 \\
2014 & 81,23 & 1,83 \\
\hline Jumlah & $\mathbf{4 0 0 , 3 1}$ & $\mathbf{1 , 7 3}$ \\
\hline Rata-rata & $\mathbf{8 0 , 1}$ & $\mathbf{0 , 3 5}$ \\
\hline
\end{tabular}

Th 2004 tentang kedudukan dalam membuat suatu kebijakan hasil perundingan serta keuangan pimpinan dan anggota Dewan dalam melaksanakan tupoksinya.

Untuk mencapai tujuan sebuah organisasi, baik organisasi pemerintahan maupun non pemerintahan perlu adanya manajemen atau pengelolaan yang baik dari seorang pimpinan atau seorang ketua dari organisasi atau lembaga tersebut. Dalam organisasi pemerintah maupun non pemerintah sumber daya manusia menjadi asset yang penting karena perannya dalam pelaksanaan strategi sangat penting yaitu seabagai objek pelaksanaan, pelayanan dan strategi organisasi. Upaya pemerintahan daerah dalam pelayanan publik mencoba terus ditingkatkan, peningkatan pelayanan publik harus dibarengi dengan kemampuan pemerintahan daerah itu sendiri dalam menjalan tugas poko dan fungsinya sebagai lembaga pemerintahan. Unsur utama yang menentukan dalam

Dari Tabel 1 rata-rata DP3 pegawai DPRD Kabupaten Bogor terlihat fluktuatif kinerja pegawai dari setiap tahunnya, dilihat dari ratarata perubahannya dari setiap tahunnya meningkat sebesar $0,35 \%$. Harapan peningkatan untuk para pegawai sebesar $2 \%$ dalam hal ini terlihat bahwa para pegawai diduga dalam hal komitmen belum optimal karena belum sesuai dengan harapan.

\section{MATERI DAN METODE}

\section{Komitmen Organisasi}

Kata komitmen berasal dari bahasa latin "Commiter" yang berarti menggabungkan, menyatukan, mempercayai dan mengerjakannya (Snyder, 1994). Robbins, SP dan Judge (2008) menjelaskan bahwa komitmen organisasi merupakan suatu keadaan seorang individu memihak organisasi dengan tujuan dan keinginannya untuk mempertahankan keanggotaannya dalam organisasi. Mathias dan Jackson (dalam Sopiah, 2008) mendefinisikan komitmen organisasi merupakan suatu derajat dimana para pegawai percaya dan mau 
menerima tujuan-tujuan organisasi serta terus tetap tinggal dan atau tidak dalam organisasinya.

Mowday (dalam Sopiah, 2008) menjelaskan ada tiga aspek dalam komitmen organisasi, yaitu

1. Affective Commitment, hal ini berhubungan dengan keinginan pegawai untuk terikat pada organisasi. Seorang pegawai menetap dalam oragnisai karena keinginan sendiri. Kunci dalam hal ini adalah want to.

2. Continuance Commitmen, adalah suatu komitmen oragnisasi yang didasarkan terhadap kebutuhan rasional. Artinya dalam komitmen ini terbentuk pada dasar perhitungan untung rugi dengan mempertimbangkan apa yang dikorbankan apabila menetap pada organisasi ini. Kata kunci dari komitmen ini yaitu kebutuhan bertahan untuk tetap dalam organisasi ini (need to).

3. Normative commitment, adalah suatu komitmen organisasi yang berdasarkan kepada normayang ada apada karyawan atau pegawai yang mempunyai keyakinan akan tanggung jawab pada organisasi yang dilaksanakan dan pegawai merasa harus tetap bertahan pada organisasi ini. Kunci dalam komitmen tersebut yaitu kewajiban tetap bertahan pada organisasi (ought to).

\section{Karakteristik Individu}

Manusia adalah makhluk hidup yang bias terlihat dari berbagai sudut. Manusia memiliki suatu objek yang formal dalam membahas tentang hakikat manusia dengan apa adanya dalam berbagai kondisinya. Sebagaimana diketahui, bahwa manusia itu makhluk yang dapat berpikir (homo sapiens), manusia yang berbentuk (homo fiber), makhluk yang dapat dididik atau edu-candum, dan seterusnya. Hal ini merupakan asumsi-asumsi tentang manusia yamg dapat dipakai untuk menetapkan cara pendekatan yang akan dilakukan tehadap manusia tersebut.

Sumber daya yang penting pada organisasi yaitu potensi yang dimiliki oleh manusia atau sering kita sebut yaitu sumber daya manusia, karena dalam sumber daya manusia ini berbicara tentang orang-orang yang memberikan tenaga, bakat, kreativitas, dan usaha karyawan dalam organisasi untuk membuat organisasi itu tetap eksistensi. Setiap manusia mempunyai sifat dan karakter yang berbeda antara individu dengan individu lainnya. Karakteristik individu membawa kepada tatanan organisasi kemampuan, kepercayaan diri, pengharapan kebutuhan, dan pengalaman masa lampaunya. Ini semua karakteristik yang dimiliki individu serta karakteristik ini yang selalu dibawa oleh individu tersebut manakala memasuki lingkungan yang baru atau organisasi baru (Thoha, Miftah 2011). Pada tingkatan individu, karakteristik dari setiap individu (personal) yang meliputi: ciri pribadi atau biografis seperti: usia, jenis kelamin, status perkawinan, ciri kepribadian, nilai, sikap dan tingkat kemampuan dasar tersebut akan mempengaruhi perilaku individu ditempat kerja (Robbins, 2003).

Rivai (2004) mendefinisikan bahwa karakteristik personal adalah ciri khusus, sifat kejiwaan, budi pekerti atau akhlak yang dimiliki seseorang membedakannya dengan individu lain. Muchlas (2005) menyatakan bahwa variabel-variabel karakteristik individu juga dapat berupa karakteristik biografi, kepribadian, kemampuan dan proses belajar. Robbins (2003) menjelaskan bahwa ada 4 (empat) variabel karakteristik individu yaitu karakteristik biografis (meliputi usia, jenis kelamin, status kawin, tanggungan hidup dan masa kerja), kemampuan individu (meliputi kemampuan intelektual dan kemampuan fisik), pembelajaran dan kepribadian. Disebutkan juga bahwa kemampuan mampu mempengaruhi langsung kepuasan seorang karyawan lewat kesesuaian kemampuan pekerjaan

Menurut Robbins \& Judge (2008), "Kemampuan (ability) adalah kemampuan seseorang dalam melakukan berbagai tugas dalam sebuah pekerjaan. Kemampuan keseluruhan seorang individu pada dasarnya terdiri atas dua kelompok faktor yaitu:

1. Kemampuan Intelektual 
Kemampuan intelektual merupakan kemampuan yang dibutuhkan dalam melaksanakan atau menjalankan kegiatan mental. Ada 7 (tujuh) dimensi dalam menumbuhkan dan membentuk kemampuan intelektual, yakni:

a. Kecerdasan dalam berhitung atau numerik yaitu kemampuan atau keahlian untuk berhitung secara tepat dan cepat.

b. Kemampuan verbal yaitu kemampuan untuk memahami apa yang dibaca atau didengarkan serta hubungannya antara kata satu dengan kata yang lain.

c. Kecepatan perseptual adalah kemampuan mengenali kemiripan dan perbedaan visual dengan secara tepat.

d. Penalaran induktif adalah kemampuan mengenal suatu urutan yang logis dalam satu masalah dan mampu memecahkannya.

e. Penalaran deduktif adalah kemampuan dalam berlogika untuk menilai suatu argumen.

f. Visualisasi ruang adalah kemampuan membayangkan suatu obyek apabila posisi ruangan diubah.

g. Ingatan adalah kemampuan dalam menahan dan mengenang pengalaman masa lalu.

2. Kemampuan Fisik

Kemampuan fisik adalah kemampuan yang dibutuhkan dalam melaksanakan tugas-tugas yang memerlukan stamina yang prima, kecekatan, kekuatan dan keterampilan yang lebih. Kemampuan intelektual memainkan fungsi yang lebih dominan dalam pekerjaan-pekerjaan rumit yang menuntut persyaratan pemprosesan informasi, sementara kemampuan fisik sangat dibutuhkan dalam melaksanakan tugas dan pekerjaan yang keberhasilannya memerlukan stamina yang kuat, kecekatan tangan yang baik, kekuatan tungkai atau bakat-bakat serupa.

\section{Gaya Kepemimpinan}

Thoha (2011) gaya kepemimpinan adalah suatu norma atau perilaku yang digunakan oleh seorang pemimpin untuk mempengaruhi perilaku orang lain atau bawahan. Kepemimpinan selalu berhubungan dengan kemampuan untuk mempengaruhi katawan atau bawahannya dalam suatu kelompok untuk tercapainya suatu tujuan, sehingga kepemimpinan selalu menyangkut dalam hal mengatasi perubahan. Seorang pemimpin secara khusus tercermin melalui gaya kepemimpinannya. Melalui gaya kepemimpinan yang dimiliki oleh seorang pemimpin, ia akan mentransferkan beberapa nilai seperti penekanan terhadap kelompok, dukungan terhadap pegawai, toleransi, kriteria gaji atau pengupahan dan lain sebagainya. Gaya kepemimpinan seorang pimpinan akan mempengaruhi kondisi kerja, motivasi dan kepuasan kerja, menumbuhkan komitmen pegawai terhadap organisasi dapat mengakibatkan peningkatan etos kerja dan sebaliknya juga akan menyebabkan penurunan kinerja jika penerapan komitmen kepada pegawainya tidak sesuai dengan kondisi kerja dari para anggota organisasi (Gibson, 2000).

Thoha, (2011) memaparkan tentang bebrapa teori kepemimpinan, teori-teori tersebut antara lain sebagai berikut :

1. Teori Sifat (Trait Theory)

Pertama kali muncul tentang teori sifat ini berawal pada zaman yunani kuno dan zaman romawi. Pada zaman tersebut semua orang percaya bahwa seorang pemimpin itu dilahirkan atau sudah menjadi takdir, tidak dibuat atau dibina.

2. Teori Kelompok

Teori kelompok pada kepemmipinan ini dasar perkembangannya berawal pada psikologis sosial dan teori pertukaran yang klasik, membantunya sebagai suatu dasar penting bagi pendekatan teori kelompok. Teoru kelompok ini beranggapan bahwa agar suatu kelompok dapat mencapai tujuantujuannya maka harus terdapat suatu 
pertukaran yang positif diantara pemimpin dan pengikut-pengikutnya.

3. Teori Situasional dan Kontijensi Dimulai pada sekitar tahun 1940-an para ahli psikologis sosial mulai menliti beberapa variabel situasional yang mempunyai pengaruh terhadap kepemimpinan, kecapakapan dan perilakunya berikut pelaksanaan kerja dan kepuasan kerjanya.

4. Model Kepemimpinan Kontijensi dari Fiedler

Untuk menguji hipotesis yang sudah dirumuskan dari penelitian-penelitian terdahulu, Fiedler mencoba mengembangkan model kepemimpinan yang dinamakan Model Kontijensi Kepemimpinan Efektif (A Countingency Model Of Leadership Effectiveness). Model model ini menjelaskan tentang hubungan gaya kepemimpinan dengan situasi yang menyenangkan. Adapun situasi tersebut dijelaskan oleh Fielder hubungannya dengan dimensi-dimensi empiris yang dilakukan sebagai berikut :

a. Hubungan pemimpin-anggota. hal ini merupakan hal terpenting untuk menentukan situasi yang menyenangkan tersebut.

b. Tingkat dari struktur tugas. Dimensi ini merupakan suatu masukkan yang sangat penting, untuk menentukan situasi yang menyenangkan.

c. Posisi kekuasaan yang dicapai melalui otoritas formal. Dimensi ini menjadi dimensi yang sangat penting juga untuk menentukan situasi menyenangkan.

5. Model kepemimpinan Teori Jalan KecilTujuan (Path-Goal Theory) Adapun teori Path-Goal versi House ini menjelaskan dan memasukkan empat tipe atau gaya kepemimpinan sebagai berikut :

a. Kepemimpinan direktif.

Tipe ini sama dengan kepemimpinan yang otokratis dari Lippit dab White. Bawahan mengetahui apa yang diinginkan dari pimpinannya dan melakukan pengarahan khusus yang diberikan oleh pemimpin. Dalam model kepemimpinan ini tidak ada partisipasi dari bawahan.

b. Kepemimpinan yang mendukung (supportive leadership).

Kepemimpinan seperti ini mempunyai kesediaan untuk menjelaskan sendiri, bersahabat, mudah bergaul, dan mempunyai perhatian yang ikhlas kepada pegawainya.

c. Kepemimpinan partisipatif.

Gaya kepemimpinan parsitipatif ini, pemimpin meminta saran dan masukkan serta mempergunakan saran dan masukkan dari bawahannya namun keputusan tetap ada padanya.

d. Kepemimpinan berorientasi pada prestasi.

Gaya kepemimpinan ini membuat serangkain tujuan perusahaan yang menantang bagi pegawai atau bawahannya untuk berprestasi.

6. Pendekatan Social Learning.

Pendekatan ini memberikana suatu dasar untuk suatu model konsepsi yang menyeluruh bagi perilaku organisasi. Social learning adalah suatu teori kepemimpinan yang mampu menjamin kelangsungan, interaksi timbal-balik antara pemimpin, lingkungan dan perilakunya sendiri.

\section{Budaya Organisasi}

Menurut Robbins (2003), budaya organisasi merupakan suatu sistem makna bersama yang dianut oleh para anggota yang membedakan suatu organisasi dengan organisas lain. Budaya atau kultur organisasi dapat dikatakan dengan sederhana sebagai kepribadian atau perasaan organisasi. Kultur organisasi mempengaruhi cara manusia bertindak dalam organisasi, bagaimana mereka bekerja, memandang pekerjaan, bekerjasama dengan rekan kerja, dan 
menatap masa depan yang sebagian besar ditentukan oleh norma kultural, nilai-nilai dan kepercayaan mereka.

Keberhasilan organisasi dewasa ini salah satunya dilihat dari budaya dan kemampuannya dalam mentransformasikan diri guna mendukung tujuan organisasinya. Dalam rangka mempertahankan kelangsungan hidup organisasi harus mampu mengembangkan potensi yang dimiliki sumber daya manusia dan memperkuat budaya, sehingga dapat menyesuaikan dengan perubahan budaya dalam menjalankan fungsinya sebagai salah satu mekanisme pembuat makna dan kendali organisasi yang nantinya akan membina dan membentuk sikap serta perilaku karyawan atau pegawai (Robbins, 2003).

Budaya organisasi menjadi sangat berarti untuk kelangsungan hidup suatu organisasi terutama bila dihubungkan dengan upaya untuk mengatasi berbagai masalah dalam hal adaptasi atas berbagai perubahan serta perkembangan diluar dan integrasi terhadap kekuatan internal (Schein, 1992).

Menurut Robbins (1996), ada tujuh ciri-ciri budaya organisasi, yaitu sebagai berikut :

1. Inovasi pengambilan resiko.

2. Perhatian terhadap detail.

3. Berorientasi terhadap hasil.

4. Berorientasi terhadap orang.

5. Berorientasi pada tim.

6. Agresivitas.

7. Kemantapan.

Secara skematis, pengaruh karakteristik individu, gaya kepemimpinan dan budaya organisasi terhadap komitmen organisasi dapat dilihat pada gambar 1 sebagai berikut :

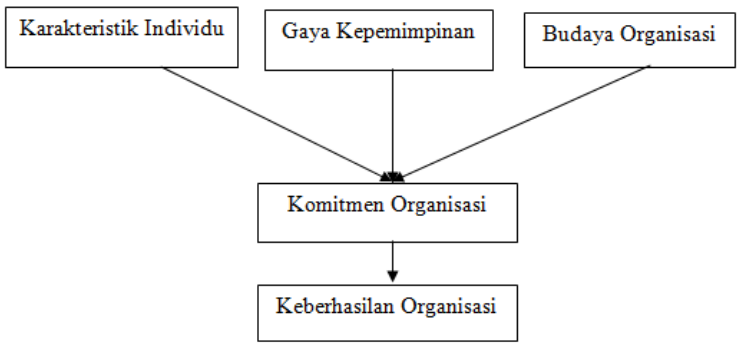

Gambar 1. Kerangka Pemikiran

\section{Hipotesis}

Berdasarkan uraian di atas dapat dikemukakan bahwa hipotesis pada penelitian ini yaitu sebagai berikut :

1. Adanya pengaruh karakteristik individu, gaya kepemimpinan dan budaya organisasi secara positif dan signifikan terhadap komitmen organisasi secara simultan.

2. Adanya pengaruh karakteristik individu, gaya kepemimpinan, dan budaya organisasi secara positif dan signifikan terhadap komitmen organisasi secara parsial.

\section{Metode Analisis}

Data yang terkumpul akan dianalisis secara deskriptif dan kuantitatif menggunakan uji statistik. Analisis regresi berganda menurut Sugiyono, (2014) adalah alat untuk meramalkan atau memperkirakan nilai pengaruh dua variabel bebas atau lebih terhadap satu variabel terikat (untuk membuktikan apakah ada tidaknya hubungan fungsional atau hubungan kausal antara dua atau lebih variabel bebas).

Untuk mengetahui ada atau tidaknya pengaruh yang signifikan dan positif antara karakteristik individu, gaya kepemimpinan dan budaya organisasi terhadap komitmen organisasi, digunakan rumus analisis regresi linear berganda sebagai berikut:

$$
Y=a+\beta_{1} X_{1}+\beta_{2} X_{2}+\beta_{3} X_{3}+\varepsilon
$$

Dimana :

$\mathrm{Y}=$ Variabel Terikat Komitmen Organisasi

$\mathrm{A}=$ Konstanta

$\beta_{1}=$ Koefisien Regresi Karakteristik Individu

$\beta_{2}=$ Koefisien Regresi Gaya Kepemimpinan

$\beta_{3}=$ Koefisien Regresi Budaya Organisasi

$\mathrm{X}_{1}=$ Variabel Bebas Karakteristik individu

$\mathrm{X}_{2}=$ Variabel Bebas Gaya Kepemimpinan

$\mathrm{X}_{3}=$ Variabel Bebas Budaya Organisasi

$\mathcal{E}=$ Faktor lain yang tidak diteliti

Dalam menguji hipotesis penelitian yang akan dilaksanakan maka menggunakan uji statistik dengan model penelitian seperti yang terlihat pada gambar berikut. 
Gambar 2. Hubungan Antara Variabel Penelitian

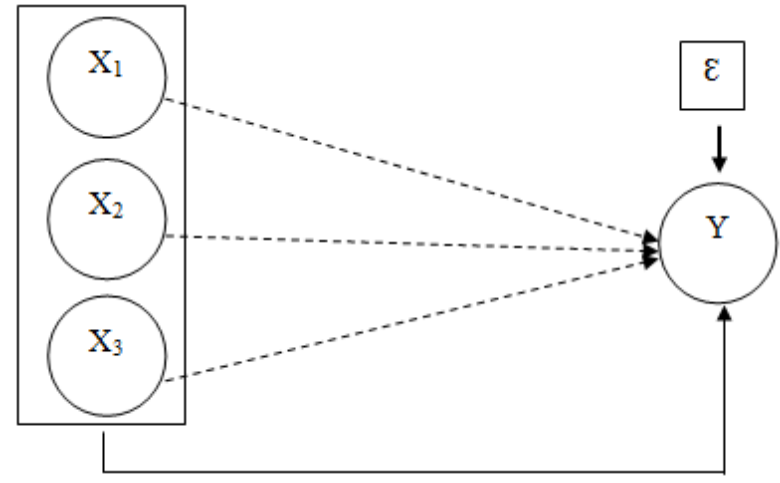

Dimana :

$\begin{array}{lll}\longrightarrow & \begin{array}{l}\text { Pengaruh Parsial } \\ \longrightarrow\end{array} & \text { Pengaruh Simultan } \\ \mathrm{X}_{1} & = & \text { Karakteristik Individu } \\ \mathrm{X}_{2} & = & \text { Gaya Kepemimpinan } \\ \mathrm{X}_{3}= & \text { Budaya Organisasi } \\ \mathrm{Y}= & \text { Komitmen Organisas } \\ \varepsilon & = & \text { Variabel lain yang tidak diteliti }\end{array}$

\section{Pengujian Hipotesis}

Dalam menguji signifikansi hubungan variabel bebas (independent) dengan variabel terikat (dependent) secara simultan, maka menggunakan uji F (Sugiyono, 2014). Tingkat signifikan $(\alpha)=0,05$. Hubungan variable bebas (independent) secara simultan dengan variabel terikat (dependent), dalam menguji variable tersebut apakah variable bebas itu berpengaruh positif dan signifikan terhadap variable terikat secara simultan dengan $\alpha=0,05$ dan juga penerimaan atau penolakan hipotesa.
Hubungan variable bebas (independent) secara parsial dengan variable terikat (dependent), dalam menguji apakah setiap masing-masing variabel bebas berpengaruh positif dan signifikan terhadap variabel terikat secara parsial dengan $\alpha=0,05$ dan juga penerimaan atau penolakan hipotesa, maka cara yang dilakukan adalah: dalam menguji apakah setiap masing-masing variabel bebas (karakteristik individu, gaya kepemimpinan, dan budaya organisasi) berpengaruh terhadap komitmen organisasi sebagai variabel terikat secara satu per satu (parsial) dengan $\alpha=0,05$ dan juga penerimaan atau penolakan hipotesa (Sugiyono, 2014).

\section{HASIL DAN PEMBAHASAN}

\section{Karakteristik Responden}

Berdasarkan Tabel 1 di bawah dapat terlihat bahwa karakteristik responden pegawai Sekretariat DPRD Kabupaten Bogor adalah didominasi laki-laki dengan pertimbangan memilliki stamina yang kuat, dan pegawai ratarata memiliki usia yang muda karena usia tersebut usia yang produktif dan mempunyai stamina yang kuat juga lalu untuk pendidikan dimayoritasi oleh lulusan SMA karena dibutuhkan pegawai untuk ditempatkan pada bagian fungsional sub bidang yang hanya memerlukan pendidikan formal yang tidak tinggi dan lama kerja para pegawai masih dalam tahap peningkatan komitmen dan loyalitas.

Tabel 1. Karakteristik Responden

\begin{tabular}{lccc}
\hline \multicolumn{1}{c}{ Karakteristik } & Ketrangan & Jumlah & \% \\
\hline Jenis Kelamin & Laki-laki & 52 & 75,36 \\
Usia & $35-44$ & 33 & 47,83 \\
Pendidikan Terakhir & Sederajat SMA & 33 & 47,83 \\
Lama Kerja & $1-10$ & 46 & 66,67 \\
\hline
\end{tabular}


Tabel 2. Rekapitulasi Tanggapan Responden Untuk Variabel Karakteristik Individu

\begin{tabular}{llcc}
\hline No & \multicolumn{1}{c}{ Pertanyaan / Pernyataan } & Jawaban & Keterangan \\
\hline 1 & $\begin{array}{l}\text { Saya memiliki kemampuan berhitung secara cepat dan tepat } \\
2\end{array}$ & 3,23 & Cukup \\
& $\begin{array}{l}\text { Saya memiliki kemampuan verbal sehinga memahami apa yang dibaca } \\
\text { atau didengar serta hubungan satu sama lain }\end{array}$ & 3,50 & Baik \\
3 & $\begin{array}{l}\text { Saya memiliki kemampuan perseptual sehingga mampu mengenal } \\
\text { kemiripan dan perbedaan visual dengan cepat dan tepat }\end{array}$ & 3,29 & Cukup \\
4 & $\begin{array}{l}\text { Saya mampu mengenali suatu urutan logis dalam suatu masalah serta } \\
\text { pemecahannya }\end{array}$ & 3,16 & Cukup \\
5 & $\begin{array}{l}\text { Saya mampu menggunakan akal logika dan menilai implikasi dari suatu } \\
\text { argumen }\end{array}$ & 3,58 & Baik \\
6 & $\begin{array}{l}\text { Saya memiliki kemampuan visualisasi ruang sehingga mampu } \\
\text { membayangkan bagaiman suatu obyek akan tampak, seandainya posisi }\end{array}$ & 3,26 & Cukup \\
& $\begin{array}{l}\text { ruang diubah } \\
\text { Saya memiliki kemampuan ingatan sehingga mampu menahan ingatan } \\
\text { masa lalu dan mengenang kembali pengalaman masa lalu }\end{array}$ & 3,48 & Baik \\
8 & $\begin{array}{l}\text { Saya mempunyai stamina yang cukup baik untuk melaksanakan tugas } \\
\text { pekerjaan }\end{array}$ & 3,81 & Baik \\
9 & $\begin{array}{l}\text { Saya cekatan dalam melaksanakan dan mengerjakan tugas atau pekerjaan } \\
\text { Saya memiliki kekuatan untuk melakukan pekerjaan yang berat } \\
10\end{array}$ & 3,67 & Baik \\
Saya memiliki keterampilan yang tidak dimiliki oleh pegawai yang lain & 3,39 & Cukup \\
\hline & $\quad$ Total & $\mathbf{3 7 , 4 5}$ & Baik \\
\hline
\end{tabular}

Berdasarkan Tabel 2 di atas dapat terlihat bahwa jawaban responden untuk variabel karakteristik individu, pernyataan atau pertanyaan yang mempunyai nilai tertinggi adalah mengenai saya mempunyai stamina yang cukup baik untuk melaksanakan tugas pekerjaan sebesar 3,81 dengan penilaian baik, sehingga stamina tersebut perlu dipertahankan dan atau ditingkatkan oleh pegawai Sekretariat DPRD Kabupaten Bogor dengan cara sering melakukan olahraga dan pola hidup yang sehat dalam aktifitas bekerjanya selalu dalam stamina yang prima. Sedangkan untuk nilai terendah adalah mengenai saya mampu mengenali suatu urutan logis dalam suatu masalah serta pemecahannya sebesar 3,16 dengan penilaian cukup. Hal tersebut memperlihatkan bahwa pegawai harus dilatih atau menyediakan pelatihan untuk pegawai agar pegawai mampu berfikir secara logis dalam pemecahan masalah. Sementara itu nilai rata-rata untuk rekapitulasi variabel karakteristik individu sebesar 3,44 dengan penilaian baik. Hal tersebut memperlihatkan bahwa mayoritas pegawai sekretariat DPRD Kabupaten Bogor memiliki karakteristik individu yang baik, artinya pegawai mem- punyai satamina, kecekatan, keterampilan dan keahlian yang baik.

Berdasarkan Tabel 3 di bawah dapat dilihat bahwa jawaban responden untuk variabel gaya kepemimpinan memiliki skor tertinggi pada pernyataan pimpinan saya menekankan kepada pegawainya untuk selalu berprestasi yaitu sebesar 4,17 hal tersebut menjelaskan bahwa pegawai akan berkomitmen apabila pemimpin selalu menekankan untuk selalu berprestasi, dalam hal tersebut pemimpin harus meningkatkan kemampuan pegawai melalui pelatihan. Sedangkan pernyataan yang memiliki skor terendah adalah mengenai pimpinan saya memperlakukan pegawainya sebagai sahabat seperti tidak ada atasan atau bawahan dengan nilai sebesar 3,40. Hal ini memperlihatkan bahwa seorang pemimpin harus dapat menjaga jarak agar tidak terlalu akrab dengan pegawainya sehingga pemimpin terjaga kewibawaannya dan pegawai menjadi segan terhadap pimpinannya. Sementara itu nilai rata-rata untuk gaya kepemimpinan sebesar 3,74. Hal ini menjelaskan bahwa sebagian responden menyatakan sesuai dengan gaya kepemimpinan di sekretariat DPRD Kabupaten Bogor. 
Tabel 3. Rekapitulasi Tanggapan Responden Untuk Variabel Gaya Kepemimpinan

\begin{tabular}{clcc}
\hline No & \multicolumn{1}{c}{ Pertanyaan / Pernyataan } & Jawaban & Keterangan \\
\hline 1 & $\begin{array}{l}\text { Pimpinan mendorong pegawai untuk melakukan inovasi dan selalu kreatif } \\
2\end{array}$ & $\begin{array}{l}\text { Pegawai selalu diikut sertakan dalam pengambilan keputusan oleh } \\
\text { pimpinan }\end{array}$ & 3,35 \\
3 & $\begin{array}{l}\text { Pegawai diharapkan menunjukkan kecermatan analisis dan perhatian } \\
\text { terhadap detail }\end{array}$ & 3,72 & Kuat \\
4 & $\begin{array}{l}\text { Pimpinan memfokuskan pegawai pada hasil bukannya pada tekhnik dan } \\
\text { proses yang digunakan untuk mencapai hasil tersebut }\end{array}$ & 3,04 & Cukup \\
5 & $\begin{array}{l}\text { Dalam pengambilan keputusan pimpinan selalu memperhitungkan efek } \\
\text { pada orang-orang di dalam organisasi }\end{array}$ & 3,65 & Kuat \\
6 & $\begin{array}{l}\text { Pimpinan selalu menekankan dalam setiap kegiatan kerja diorganisasikan } \\
\text { sekitar tim-tim, bukannya individu }\end{array}$ & 3,91 & Kuat \\
7 & $\begin{array}{l}\text { Pimpinan selalu melakukan pelatihan untuk meningkatakan kualitas diri } \\
\text { pegawai dan keagresifan pegawai }\end{array}$ & 3,72 & Kuat \\
8 & $\begin{array}{l}\text { Pegawai sudah merasa mantap dalam organisasi yang sedang dijalani dan } \\
\text { enggan untuk pindah ke yang lain }\end{array}$ & 2,91 & Cukup \\
\hline \multicolumn{1}{c}{ Total } & $\mathbf{2 8 , 2 9}$ & $\mathbf{3 , 5 4}$ & Kuat \\
\hline
\end{tabular}

Tabel 4. Rekapitulasi Tanggapan Responden Untuk Variabel Budaya Organisasi

\begin{tabular}{|c|c|c|c|}
\hline No & Pertanyaan / Pernyataan & Jawaban & Keterangan \\
\hline 1 & Pimpinan mendorong pegawai untuk melakukan inovasi dan selalu kreatif & 3,99 & Kuat \\
\hline 2 & $\begin{array}{l}\text { Pegawai selalu diikut sertakan dalam pengambilan keputusan oleh } \\
\text { pimpinan }\end{array}$ & 3,35 & Cukup \\
\hline 3 & $\begin{array}{l}\text { Pegawai diharapkan menunjukkan kecermatan analisis dan perhatian } \\
\text { terhadap detail }\end{array}$ & 3,72 & Kuat \\
\hline 4 & $\begin{array}{l}\text { Pimpinan memfokuskan pegawai pada hasil bukannya pada tekhnik dan } \\
\text { proses yang digunakan untuk mencapai hasil tersebut }\end{array}$ & 3,04 & Cukup \\
\hline 5 & $\begin{array}{l}\text { Dalam pengambilan keputusan pimpinan selalu memperhitungkan efek } \\
\text { pada orang-orang di dalam organisasi }\end{array}$ & 3,65 & Kuat \\
\hline 6 & $\begin{array}{l}\text { Pimpinan selalu menekankan dalam setiap kegiatan kerja diorganisasikan } \\
\text { sekitar tim-tim, bukannya individu }\end{array}$ & 3,91 & Kuat \\
\hline 7 & $\begin{array}{l}\text { Pimpinan selalu melakukan pelatihan untuk meningkatakan kualitas diri } \\
\text { pegawai dan keagresifan pegawai }\end{array}$ & 3,72 & Kuat \\
\hline \multirow[t]{2}{*}{8} & $\begin{array}{l}\text { Pegawai sudah merasa mantap dalam organisasi yang sedang dijalani dan } \\
\text { enggan untuk pindah ke yang lain }\end{array}$ & 2,91 & Cukup \\
\hline & $\begin{array}{c}\text { Total } \\
\text { Rata-rata }\end{array}$ & $\begin{array}{c}28,29 \\
3,54\end{array}$ & Kuat \\
\hline
\end{tabular}

Berdasarkan Tabel 4 di atas dapat terlihat bahwa jawaban responden untuk variabel budaya organisasi, pernyataan atau pertanyaan yang memiliki nilai tertinggi adalah mengenai pimpinan mendorong pegawai untuk melakukan inovasi dan selalu kreatif dengan nilai sebesar 3,99 menunjukkan bahwa pemimpin harus mengadakan pelatihan atau kegiatan apapun itu agar kreatifitas dan inovasi pegawai dapat dipertahankan atau bahkan dapat ditingkatkan. Sedangkan nilai terendah adalah mengenai pegawai sudah merasa mantap dalam organisasi yang sedang dijalani dan enggan untuk pindah ke yang lain dengan nilai sebesar 2,91. Hal tersebut menjelaskan bahwa pemimpin harus mampu membuat dirinya egaliter terhadap pegawainya agar pegawainya merasa nyaman dalam 
organisasinya sehingga mengakibatkan pegawainya untuk enggan berpindah ke organisasi lain. Sementara itu nilai rata-rata untuk budaya organisasi sebesar 3,54. Ini menjelaskan bahwa pegawai DPRD Kabupaten Bogor memiliki budaya organisasi yang kuat dalam organisasinya.

Berdasarkan Tabel 5 tersebut, dapat terlihat bahwa jawaban responden untuk variabel harus dikembangkan dan atau dipertahankan lagi dengan cara pemimpin dan pegawai harus sering berkumpul bersama baik dalam lingkungan pekerjaan atau diluar pekerjaan sehingga terjalin rasa kekeluargaannya. Sedangkan untuk nilai terendah adalah mengenai saya tidak berkewajiban berpindah dari organisasi satu keorganisasi lain, karena tidak etis bagi saya, memiliki nilai sebesar 2,90.

Tabel 4. Rekapitulasi Tanggapan Responden Untuk Variabel Budaya Organisasi

\begin{tabular}{|c|c|c|c|}
\hline No & Pertanyaan / Pernyataan & Jawaban & Keterangan \\
\hline 1 & Saya ingin menghabiskan sisa karir saya di organisasi ini & 3,17 & Cukup \\
\hline 2 & $\begin{array}{l}\text { Saya ingin membanggakan organisasi ini kepada orang lain di luar } \\
\text { organisasi }\end{array}$ & 3,51 & Tinggi \\
\hline 3 & $\begin{array}{l}\text { Saya ingin merasakan seakan-akan permasalahan organisasi adalah } \\
\text { permasalahan saya sendiri }\end{array}$ & 3,07 & Cukup \\
\hline 4 & Saya ingin menjadi bagian dari keluarga pada organisasi ini & 3,77 & Tinggi \\
\hline 5 & Saya ingin terikat secara emosional pada organisasi ini & 3,29 & Cukup \\
\hline 6 & Saya ingin memiliki arti dalam organisasi ini & 3,65 & Kuat \\
\hline 7 & $\begin{array}{l}\text { Saya sangat membutuhkan pekerjaan ini karna belum tentu saya dapat } \\
\text { merasa nyaman dalam pekerjaan lain }\end{array}$ & 3,57 & Kuat \\
\hline 8 & $\begin{array}{l}\text { Saya membutuhkan organisasi ini sehingga akan sangat merugikan saya } \\
\text { apabila saya meninggalkan organisasi ini sekarang }\end{array}$ & 3,14 & Tinggi \\
\hline 9 & $\begin{array}{l}\text { Saat ini tetap bekerja di organisasi ini merupakan kebutuhan sekaligus } \\
\text { keinginan saya }\end{array}$ & 3,45 & Tinggi \\
\hline 10 & Saya membutuhkan organisasi ini karena karirnya jelas dan cepat & 3,03 & Cukup \\
\hline 11 & $\begin{array}{l}\text { Salah satu alasan utama saya melanjutkan bekerja untuk organisasi ini } \\
\text { adalah bahwa meninggalkan organisasi akan membutuhkan pengorbanan } \\
\text { pribadi yang besar, organisasi lain mungkin tidak akan sesuai dengan } \\
\text { keseluruhan manfaat yang saya dapat disini }\end{array}$ & 2,91 & Cukup \\
\hline 12 & $\begin{array}{l}\text { Saya yakin terhadap organisasi yang saya jalani sekarang dan bertanggung } \\
\text { jawab untuk mencapai tujuan organisasi }\end{array}$ & 3,58 & Tinggi \\
\hline 13 & $\begin{array}{l}\text { saya tidak berkewajiban berpindah dari organisasi satu ke organisasi lain, } \\
\text { karena tidak etis bagi saya }\end{array}$ & 2,90 & Cukup \\
\hline 14 & $\begin{array}{l}\text { Saya wajib bertahan dalam organisasi ini karena saya percaya loyalitas } \\
\text { adalah penting dan oleh karena itu saya merasa tetap bekerja di } \\
\text { perusahaan merupakan kewajiban moral }\end{array}$ & 3,39 & Cukup \\
\hline 15 & $\begin{array}{l}\text { Jika saya memperoleh tawaran pekerjaan yang lebih baik di organisasi } \\
\text { lain, saya tidak akan merasa bahwa tawaran tersebut merupakan alasan } \\
\text { yang tepat untuk meninggalkan organisasi saya }\end{array}$ & 3,41 & Tinggi \\
\hline \multirow[t]{2}{*}{16} & $\begin{array}{l}\text { Yang lebih baik saat ini adalah setiap orang berkewajiban bekerja di satu } \\
\text { organisasi sepanjang karir mereka }\end{array}$ & 3,45 & Tinggi \\
\hline & $\begin{array}{c}\text { Total } \\
\text { Rata-rata }\end{array}$ & $\begin{array}{c}53,29 \\
3,33\end{array}$ & Cukup \\
\hline
\end{tabular}

komitmen organisasi, pernyataan atau pertanyaan yang memiliki nilai tertinggi adalah mengenai saya ingin menjadi bagian keluarga dari organisasi ini sebesar 3,77 hal tersebut
Hal tersebut menjelaskan ketidak komitmenan pegawai dalam organisasi yang sedang dijalani sehingga pemimpin harus meningkatkan agar pegawai betah dalam organisasi ini dengan cara pelatihan-pelatihan atau dengan berkumpul 
bersama dengan pegawai. Sementara itu nilai rata-rata untuk komitmen organisasi sebesar 3,33. Hal tersebut menjelaskan bahwa pegawai DPRD Kabupaten Bogor memiliki komitmen organisasi yang cukup sehingga perlu peningkatan lagi komitmen dari setiap pegawainya.

\section{Hasil Estimasi Persamaan Regresi}

Bentuk persamaan regresi dapat dihitung dengan menggunakan analisis regresi berganda. Adapun persamaan tersebut adalah untuk menunjukkan pengaruh karakteristik individu, gaya kepemimpinan, dan budaya organisasi terhadap komitmen organisasi pada sekretariat DPRD Kabupaten Bogor. Berdasarkan hasil penelitian tersebut maka diperoleh suatu persamaan regresi dengan model taksiran sebagia berikut : $Y=\mathbf{- 1 , 4 0 7}+\mathbf{0 , 7 6 5} X_{1}-\mathbf{0 , 3 3 9 X _ { 2 }}$ $+\mathbf{1}, \mathbf{4 4 7} \mathrm{X}_{3}+\mathcal{E}$. Dari persamaan regresi berganda tersebut dapat diketahui sebagai berikut :

1. Koefisisen regresi dari karakateristik individu $\left(\beta_{1}\right)$

Nilai koefisien untuk variabel karakteristik individu positif artinya jika nilai variabel independen tetap serta karakteristik individu mengalami kenaikan atau meningkat, maka variabel dependen yaitu komitmen organisasi akan mengalami kenaikan. Koefisien bernilai positif yaitu antara karakteristik individu dengan komitmen organisasi, semakin baik karakteristik individu semakin baik komitmen organisasi atau sebaliknya.

2. Koefisien regresi dari gaya Kepemimpinan $\left(\beta_{2}\right)$

Nilai koefisien untuk variable gaya kepemimpinan negatif maksudnya apabila nilai variabel independennya tetap serta gaya kepemimpinan mengalami kenaikan, maka variabel dependen yaitu komitmen organisasi akan terjadi penurunan atau sebaliknya.

3. Koefisien regresi dari budaya Organisasi $\left(\beta_{3}\right)$

Nilai koefisien untuk variabel budaya organisasi positif artinya apabila nilai variabel independennya tetap serta budaya organisasi mengalami kenaikan, maka variabel dependen yaitu komitmen organisasi mengalami kenaikan. Koefisien bernilai positif yaitu antara budaya organisasi dengan komitmen organisasi, semakin baik budaya organisasi semakin baik juga komitmen organisasi atau sebaliknya.

Adapun hubungan korelasi antara karakteristik individu, gaya kepemimpinan, dan budaya organisasi terhadap komitmen organisasi memiliki hubungan korelasi yang kuat. Hal tersebut menjelaskan bahwa semakin baik karakteristik individu, gaya kepemimpinan, dan budaya organisasi maka diduga juga akan meningkatkan komitmen organisasi.

Besarnya pengaruh variabel bebas terhadap variabel terikat secara simultan dapat terlihat dari nilai $R$ Square. Nilai koefeisien determinasi $\left(\mathrm{R}^{2}\right)=0,528$. Hal tersebut menjelaskan bahwa presentase sumbangan variabel karakteristik individu $\left(\mathrm{X}_{1}\right)$, gaya kepemimpinan $\left(\mathrm{X}_{2}\right)$, dan budaya organisasi $\left(\mathrm{X}_{3}\right)$ terhadap komitmen organisasi (Y) sebesar 52,8\%. Sedangkan sisanya sebesar $47,2 \%$ dipengaruhi atas variabel lain seperti: kepuasan kerja, stres, motivasi, kepercayaan, keadilan dan etika, pembelajaran serta pengambilan keputusan (Colquitt, LePine, dan Wesson 2009).

\section{Pengujian Model Regresi Secara Simultan (Uji F)}

Untuk melihat dengan jelas pengaruh karakteristik individu, gaya kepemimpinan, dan budaya organisasi terhadap komitmen organisasi secara statistik dilihat dari nilai uji F. Berdasarkan nilai $\mathrm{F}_{\text {hitung }}$ sebesar 24,194 dan nilai $\mathrm{F}_{\text {tabel }}$ untuk $\alpha=$ 0.05 dengan derajat kebebasan 65 sebesar 2,75 yang dimana bisa dilihat Fhitung lebih besar dari $F_{\text {tabel }}(24,194>2,75)$ maka dapat disimpulkan bahwa Ha diterima dan Ho ditolak artinya dengan tingkat kepercayaan $95 \%$ variabel independen karakteristik individu $\left(\mathrm{X}_{1}\right)$, gaya kepemimpinan $\left(\mathrm{X}_{2}\right)$, dan budaya organisasi $\left(\mathrm{X}_{3}\right)$ berpengaruh positif dan signifikan secara simultan terhadap variabel dependent komitmen organisasi (Y). 


\section{Pengujian Model regresi secara parsial (Uji t)}

Uji $t$ digunakan dengan membandingkan $t_{\text {hitung }}$ dan $t_{\text {tabel. }}$. Jika $t_{\text {hitung }}$ lebih besar dari $t_{\text {tabel }}$ $\left(t_{\text {hitung }}>t_{\text {tabel }}\right)$ maka menunjukan bahwa variabel independent berpengaruh secara parsial terhadap variabel dependent. Adapun pengaruhnya secara parsial sebagai berikut :

\section{Pengaruh karakteristik individu terhadap komitmen organisasi}

Untuk mengetahui ada dan atau tidaknya pengaruh karakteristik individu terhadap komitmen organisasi dilihat nilai uji t. Berdasarkan nilai $t_{\text {hitung }}$ pada variabel karkateristik individu $\left(\mathrm{X}_{1}\right)$ sebesar 3,915 dan nilai $t_{\text {tabel }}$ sebesar 1,668 berarti $t_{\text {hitung lebih }}$ besar dari $t_{\text {tabel }}(3,915>1,668)$. Maka dari itu Ha diterima dan Ho ditolak, artinya karakteristik individu $\left(\mathrm{X}_{1}\right)$ berpengaruh positif dan signifikan secara parsial terhadap komitmen organisasi (Y).

\section{Pengaruh Gaya Kepemimpinana} Terhadap Komitmen Organisasi

Untuk mengetahui ada dan atau tidaknya pengaruh gaya kepemimpinan terhadap komitmen organisasi dilihat dari nilai uji t. Berdasarkan nilai $t_{\text {hitung }}$ pada variabel gaya kepemimpinan $\left(\mathrm{X}_{2}\right)$ sebesar $-1,348$ dan nilai $\mathrm{t}_{\text {tabel }}$ sebesar 1,668, berarti $\mathrm{t}_{\text {hitung }}$ lebih kecil dari $t_{\text {tabel }}(-1,348 \leq 1,668)$. Maka Ha ditolak dan Ho diterima, artinya gaya kepemimpinan $\left(\mathrm{X}_{2}\right)$ berpengruh negatif dan signifikan secara parsial terhadap komitmen organisasi (Y).

3. Pengaruh Budaya Organisasi Terhadap komitmen Organisasi

Untuk mengetahui ada dan atau tidaknya pengaruh budaya organisasi terhadap komitmen organisasi dilihat dari nilai ujji t. Berdasarkan nilai $t_{\text {hitung }}$ pada variabel budaya organisasi $\left(\mathrm{X}_{3}\right)$ sebesar 4.196 dan nilai $t_{\text {tabel }}$ sebesar 1,668 , berarti $t_{\text {hitung }}$ lebih besar dari $\mathrm{t}_{\text {tabel }}(4,196>1,668)$. Maka Ha diterima dan Ho ditolak, artinya bahwa budaya organisasi $\left(\mathrm{X}_{3}\right)$ berpengaruh positif dan signifikan secara parsial terhadap komitmen organisasi (Y).

\section{KESIMPULAN DAN IMPLIKASI}

Berdasarkan hasil dari penelitian, maka pembahasan mengenai pengaruh karakteristik individu, gaya kepemimpinan, dan budaya organisasi terhadap komitmen organisasi di Sekretariat DPRD Kabupaten Bogor diperoleh kesimpulan sebagai berikut:

1. Secara simultan karakteristik individu $\left(\mathrm{X}_{1}\right)$, gaya kepemimpinan $\left(\mathrm{X}_{2}\right)$ dan budaya organisasi $\left(\mathrm{X}_{3}\right)$ berpengaruh positif dan signifikan terhadap komitmen organisasi (Y) pada Sekretariat DPRD Kabupaten Bogor.

2. Hasil pengujian parsial sebagai berikut :

a. Karakteristik individu $\left(\mathrm{X}_{1}\right)$ berpengaruh positif dan signifikan terhadap komitmen organisasi (Y).

b. Gaya kepemimpinan $\left(\mathrm{X}_{2}\right)$ tidak berpengaruh positif dan signifikan terhadap komitmen organisasi (Y).

c. Budaya organisasi $\left(\mathrm{X}_{3}\right)$ berpengaruh positif dan signifikan terhadap komitmen organisasi (Y).

Berdasarkan hasil dari penelitian maka ada beberapa saran agar komitmen organisasi meningkat sebagai berikut :

1. Karakteristik individu yang berada pada secretariat DPRD Kabupaten Bogor sebaiknya ditingkatkan seperti dalam hal pegawai kurang mampu mengenal suatu urutan logis dalam masalah dan pemecahannya yang diharapkan meningkatkan kinerja karena berpengaruh terhadap komitmen organisasi.

2. Budaya organisasi yang berada pada secretariat DPRD Kabupaten Bogor, sebaiknya terus ditingkatkan agar pegawai merasa lebih mantap dalam berorganisasi dan enggan untuk pindah keorganisasi yang lain, karena akan berpengaruh terhadap komitmen organisasi.

3. Kantor sekretariat DPRD Kabupaten Bo- 
gor hendaknya mengevaluasi dan memperbaiki pada gaya kepemimpinan yang lebih sesuai agar berpengaruh positif dan signifikan terhadap komitmen organisasi.

4. Bagi peneliti selanjutnya, diharapkan untuk mengkaji dan menelaah lebih lanjut mengenai faktor-faktor lain yang dapat mempengaruhi komitmen organisasi selain dari karakteristik individu, gaya kepemimpinan, dan budaya organisasi seperti kepuasan kerja, stres, motivasi, keadilan dan etika, dan pembelajaran dan pengambilan keputusan.

\section{DAFTAR PUSTAKA}

Colquitt, Jason A., Jeffery A., LePine, and Michael J. Wesson. 2009. Organizational Behaviour: Improving Performance and Commitment in the Workplace. New York: McGraw-Hill/Irwin.

Gibson, L., James, Ivancevich, M. John, and Donnelly, H. James, Jr. 2000. Organization, Behavior, Structure, Processes. USA: Tenth Edition, Irwin McGraw-Hill Inc.

Muchlas. 2005. Perilaku Organisasi. Yogyakarta : Gadjah Mada University Press
Rivai, Vietzel. 2004. Manajemen Sumber Daya Manusia Untuk Perusahaan. Cetakan pertama. PT. Raja Grafindo. Jakarta.

Robbins, S.P. 1996. Perilaku organisasi, Konsep, Kontroversi dan Aplikasi. Alih Bahasa: Hadyana Pujaatmaka. Edisi Keenam. Penerbit. PT Bhuana Ilmu Populer. Jakarta.

--. 2003. Perilaku Organisasi. Jilid I \& II, Edisi Bahasa Indonesia, Alih Bahasa, Tim Indeks. Jakarta: PT Indeks Kelompok Gramedia.

Robbins SP, dan Judge. 2008. Perilaku Organisasi, Buku 2, Jakarta : Salemba.

Schein, H Edgar. 1992. Organizational Culture and Leadership, Second Edition, Jossey Bass Publisher, San Francisco.

Snyder, C. R. 1994. The Psychology of Hope: You can get there from here. New York: The Free Press.

Sopiah. 2008. Perilaku Organisasi, PT. Rineka Cipta Cetakan ke-2.

Sugiyono. 2014. Metode Penelitian Kuantitatif, Kualitatif, Dan $R$ \& D. CV. Alfabeta. Bandung.

Thoha, Miftah. 2011. Perilaku Organisasi, Konsep Dasar dan Aplikasinya. Rajawali Pers. Jakarta. 